\title{
Non-invasive assessment of adrenocortical activity as a measure of stress in leopards (Panthera pardus)
}

\author{
Webster $\mathrm{AB}^{1 *}$, Burroughs RBJ ${ }^{2}$, Laver $\mathrm{P}^{1,3}$ and Ganswindt $\mathrm{A}^{1,4}$ \\ ${ }^{1}$ Endocrine Research Laboratory, Dept. Anatomy and Physiology, University of Pretoria, South Africa \\ ${ }^{2}$ Centre of Veterinary Wildlife Studies, Faculty of Veterinary Science, University of Pretoria, South Africa \\ ${ }^{3}$ Animal Demography Unit, Dept. of Biological Sciences, University of Cape Town, South Africa \\ ${ }^{4}$ Mammal Research Institute, Dept. of Zoology and Entomology, University of Pretoria, South Africa \\ * corresponding author: Andrea Webster (andi.webster@gmail.com)
}

\begin{abstract}
Leopards (Panthera pardus) are listed in the IUCN Red list as vulnerable, primarily due to habitat loss, natural prey base depletion and exploitation caused by various anthropogenic activities. Although protected areas are important for leopard conservation, the majority of suitable leopard habitat lies beyond protected area boundaries exposing individuals to different environmental, physiological and psychosocial stressors. This study aimed to examine the suitability of five different enzyme immunoassays (EIAs) for monitoring adrenocortical function in the leopard based on faecal glucocorticoid metabolite (fGCM) analysis. After performing an adrenocorticotrophic hormone (ACTH) stimulation test and investigating the stability of fGCM post-defaecation, faeces from free-ranging leopards in a peri-urban and a conservation area was collected to investigate the potential impact of habitat variability on glucocorticoid output. An EIA measuring fGCM with a $5 \alpha-3 \beta-11 \beta$-diol structure performed best, demonstrating a 200 - 330\% increase in $\mathrm{fGCM}$ concentrations approximately $40 \mathrm{~h}$ post-ACTH administration. Concentrations of fGCM remained quite stable for up to six-days post defaecation and showed a maximum increase of $8 \%$ and a maximum decrease of $9 \%$. Although not significantly different (MWRS $T=86, n=16, p=0.920$ ), overall median $\mathrm{fGCM}$ concentrations were $68 \%$ higher in individuals utilising the peri-urban area compared to leopards utilising the conservation area. The ranges of fGCM concentrations between sites however were similar. Individual median fGCM concentrations differed distinctly between free-ranging males and females, possibly linked to female reproductive status. The established method can now assist in addressing some of the issues facing local wildlife managers, conservationists and researchers tackling
\end{abstract}


various aspects related to leopard conservation and management under different land use practices.

Key words: ACTH Challenge, cortisol, faecal glucocorticoid metabolites, fGCM, fGCM stability post-defaecation, habitat variability.

\section{INTRODUCTION}

Historically, leopard (Panthera pardus Linnaeus, 1758) distribution extended to all continents with the exception of Australia and Antarctica (Macdonald and Loveridge 2010), but current information suggests that leopards persist globally in only $25 \%$ of their previous range (Jacobson et al. 2016). Province-wide population studies in South Africa reinforce this trend demonstrating severe declines, (as much as $40 \%$ in some areas) in leopard densities over the last four years (Swanepoel et al. 2016; Williams et al. 2017). Reasons for this include an anthropogenic-driven loss of suitable habitat, human-wildlife conflict, depletion of natural prey bases and exploitation of leopards through trophy hunting and hunting for traditional practices (Swanepoel et al. 2014), but given that this elusive predator is difficult to study in the wild, detailed population estimates are lacking (Stein and Hayssen 2013; Swanepoel et al. 2016; Williams et al. 2017). Catholic use of habitat and versatility as a generalist predator allows leopards to successfully occupy any habitat, including altered natural habitats and settled environments that offer sufficient cover for ambush hunting and which supports sufficient numbers of adequately-sized prey species (Hayward et al. 2006; Swanepoel et al. 2014). Thus, the majority of suitable leopard habitat lies beyond conservation area boundaries on private or community-owned land (Martin and De Meulenaar 1988; Boitani 1999; Marker and Dickman 2005) and leopards moving across a land-use matrix may find themselves exposed to different environmental, physiological and psychosocial stressors. The ability of individuals to cope with acute stress or the potentially harmful effects of chronic stress that can compromise reproductive ability, cause muscle atrophy and suppress the immune system (Möstl and Palme 2002) have not yet been investigated in this species.

Stress is defined as any stimulus that threatens or is perceived to threaten the homeostasis of an individual (Selye 1936). The series of adaptive mechanisms aimed at protecting an individual and restoring homeostasis is known as the stress response (Sheriff et al. 2011). When a stressor is perceived, the hypothalamic-pituitary-adrenocortical axis and the sympathoadrenomedullary system are activated, which results in an increase in glucocorticoid and catecholamine secretion (Sapolsky 2002; Palme et al. 2005). As part of the acute stress 
response, catecholamines are secreted within fractions of a second and increase the availability of glucose from energy stores (Palme et al. 2005; Sheriff et al. 2011). Glucocorticoid responses may be adaptive in the short-term; however, prolonged elevation of glucocorticoid levels due to chronic stress can be disruptive (Möstl and Palme 2002). Concentrations of glucocorticoids or their metabolites determined from biological matrices such as blood, saliva, urine or faeces, can therefore act as reliable indicators for levels of disturbance experienced by an individual (Palme et al. 2005; Sheriff et al. 2011; Möstl 2014). Non-invasive monitoring of responses to various stressors, using faeces as hormone matrix has gained popularity, particularly for the monitoring of elusive, free-roaming species (Ganswindt et al. 2012; Kersey and Dehnhard 2014). However, due to species-specific differences in steroid metabolism, any technique to monitor faecal glucocorticoid metabolite ( $\mathrm{fGCM}$ ) concentrations in a species for the first time must be thoroughly validated to ensure that the measured compounds reflect circulating concentrations of biologically active target agents (Touma and Palme 2005; Schwarzenberger 2007; Ganswindt et al. 2012). An adrenocorticotropic-hormone (ACTH) challenge test that pharmacologically induces physiological changes in circulating glucocorticoid levels is the most widely accepted physiological validation method (Touma and Palme 2005). The aim of our study was thus to examine the suitability of available enzyme immunoassays (EIAs) for noninvasive monitoring of $\mathrm{fGCM}$ concentrations from free-ranging leopards utilizing different habitats. More specifically, we a) determined stress-related physiological responses in leopard faeces by performing an adrenocorticotrophic hormone stimulation test (ACTH challenge), b) investigated the effect of bacterial metabolism and environmental factors on the stability of fGCM concentrations post-defaecation, and c) compared fGCM concentrations from freeranging leopards utilizing a conservation area and a peri-urban area.

\section{METHODS}

\section{Study animals}

For the first part of the study, two adult leopards (one male $65 \mathrm{~kg}$; one female $45 \mathrm{~kg}$ ) housed in separate but adjacent enclosures at Predator World, North West Province, South Africa, were monitored. Individuals were fed 6-8 kg portions of venison, beef, chicken, donkey or horsemeat, three times a week and the diet was supplemented with an assortment of powdered vitamins and minerals as necessary. Each enclosure provided adequate fresh water, resting sites, play items and covered "night houses" and individuals received clear visual, olfactory and auditory stimulus from other large predators kept nearby including Bengal tiger 
(Panthera tigris tigris Linnaeus, 1758), lion (Panthera leo Linnaeus, 1758) and spotted hyaena (Crocuta crocuta Erxleben, 1777).

For the second part of the study, fresh faecal material was collected from two adult leopards (one male $56 \mathrm{~kg}$; one female $46 \mathrm{~kg}$ ) housed together in the same enclosure at Lory Park Zoo, Midrand, Gauteng Province, South Africa. The enclosure contained sand-cement substrate lowlying vegetation, adequate shade, additional raised resting areas and unrestricted access to "night houses". Fresh water points situated in the open-air enclosure could be accessed at any time and the enclosure was cleaned daily. The leopards at this facility were fed $2-4 \mathrm{~kg}$ portions of horsemeat five days a week. Powdered vitamins and mineral additives supplemented their diet as required.

For the third part of the study, data from free-ranging leopards at the Hoedspruit Wildlife Estate (HWE), Maruleng Municipality, Limpopo Province, South Africa and at MalaMala Private Game Reserve (MMGR), Mpumalanga Province, South Africa, were collected. Nine individually recognized free-ranging male and female leopards utilize the $6.9 \mathrm{~km}^{2}$ peri-urban HWE, which has a road density of $6.23 \mathrm{~km}$ of $\mathrm{road} / \mathrm{km}^{2}$, is fenced on all boundaries and accommodates approximately 1100 full-time residents in housing with associated infrastructure and amenities. Approximately 27 (females 16; males 11) individually recognized leopards utilize the $125 \mathrm{~km}^{2}$ conservation area of MMGR, which has a road density of $4.12 \mathrm{~km}$ of road $/ \mathrm{km}^{2}$. The property lies open to the Sabi Sand Game Reserve $\left(650 \mathrm{~km}^{2}\right)$ to the north, south and west, and the Kruger National Park $\left(22000 \mathrm{~km}^{2}\right.$ ) to the east and accommodates approximately 209 beds associated with commercial tourist operations. Both field sites experience summer rainfall with generally frost-free winters. Altitude (250 - 700 m above sea level), mean annual rainfall (450 $700 \mathrm{~mm}$ ) and mean monthly temperatures, (min $-1^{\circ} \mathrm{C}$ and $\max 39^{\circ} \mathrm{C}$ ) for June and January respectively (Skukuza) are similar at both study sites (Fischer et al. 2014; Viljoen and Moller 2015). The study was conducted with the approval of the University of Pretoria Animal Use and Care Committee (Reference V016-16).

\section{ACTH challenge test}

The two animals at Predator World were separated on the first day of data collection and housed in adjacent enclosures for the 14-day duration of the ACTH challenge experiment. Although visual, auditory and olfactory contact was maintained between individuals through the adjoining fence for the entire monitoring period, separation was categorised as a potential stressor and thus formed part of the biological validation for the EIAs. For seven days pre- and seven days post-ACTH administration, individuals were observed from $07 \mathrm{~h} 00$ to $18 \mathrm{~h} 30$ each day 
and all faecal samples voided during this time were collected within 10 min post-defaecation, immediately frozen and stored at $-20^{\circ} \mathrm{C}$ until analysis. As enclosures could not be accessed at night, all samples voided overnight (18h30 - 07h00) were collected the following morning at $07 \mathrm{~h} 30$ and stored frozen at $-20^{\circ} \mathrm{C}$ until analysis. On day eight, each individual received an intramuscular injection of synthetic ACTH (2.3 - $2.5 \mathrm{lU} / \mathrm{kg}$, Synacthen ${ }^{\circledR}$ Depot, Novartis) delivered through $30 \mathrm{~mm}$ un-collared treatment needles by a registered veterinarian, using a short-barrel Dan-Inject ${ }^{\oplus}$ (Dan-Inject ${ }^{\oplus}$ International, Denmark) remote dart gun operating under $\mathrm{CO}_{2}$ pressure. Notably, the immobilization and translocation of a neighbouring Bengal tiger took place on day four of the experiment.

\section{Stability of faecal glucocorticoid metabolite concentration post defaecation}

To determine the effects of bacterial metabolism and environmental factors on the stability of immunoreactive fGCM concentrations post-defaecation, six fresh faecal samples were collected from the individuals housed at the Lory Park Zoo. The material was thoroughly mixed using a hand-held stick blender, and then divided into 42 subsamples of which half were stored outside under full sun and the other half under full shade conditions. Subsequently, three sub-samples were collected from the full sun and full shade treatments at time $=0 \mathrm{~h}$ as a control, and thereafter at intervals of 1 h, 6 h, 12 h, 2 days, 3 days and 6 days respectively. Collected material was immediately frozen and stored at $-20^{\circ} \mathrm{C}$ until analysis.

\section{Faecal sample collection from free-ranging leopards}

All faecal material at MMGR study site was collected opportunistically by safari guides viewing animals for tourism purposes. After a defaecation event, samples were collected, put on ice and frozen within eight hours until analysis. Faecal material collected from free-ranging individuals at HWE was located opportunistically and frozen within three hours of collection. At HWE, a 15 $\mathrm{km}$ stretch of gravel road network in the undeveloped "green zone" was checked for leopard tracks and faeces on foot each morning between $05 \mathrm{h00}$ and 09h00. When fresh leopard tracks were located, spoor was followed to locate fresh $(<10$ h) scat. Samples were individually labelled and kept cool in ice-pack containers until they could be stored frozen at $-20^{\circ} \mathrm{C}$. All samples remained frozen until they reached the Endocrine Research Laboratory, University of Pretoria for further processing.

\section{Steroid extraction and analysis}

Frozen samples were lyophilised, pulverised and sieved through a wire-mesh strainer to remove any undigested material and between $0.10-0.11 \mathrm{~g}$ of faecal powder from each sample was then mixed with $3 \mathrm{ml}$ of $80 \%$ ethanol, vortexed for $15 \mathrm{~min}$ and centrifuged for $10 \mathrm{~min}$ at $1500 \mathrm{~g}$ 
for steroid extraction. Supernatant $(1.5 \mathrm{ml})$ was decanted and stored at $-20^{\circ} \mathrm{C}$ until analysis (Ganswindt et al. 2002). Due to the absence of information regarding the presence and relative abundance of faecal glucocorticoid metabolites ( $\mathrm{fGCM}$ ) specific to the leopard, faecal steroid extracts resulting from the ACTH challenge were measured for immunoreactive $\mathrm{fGCM}$ concentrations using five different enzyme immunoassays (EIAs) namely: “(i) Cortisol, (ii) 11oxoaetiocholanolone I (detecting 11,17 dioxoandrostanes), (iii) 11-oxoaetiocholanolone II (detecting fGCMs with a $5 \beta-3 \alpha$-ol-11-one structure), (iv) Corticosterone and (v) $5 \alpha$ pregnane-3 $\beta, 11 \beta, 21$-triol-20-one (detecting fGCMs with a $5 \alpha-3 \beta-11 \beta$-diol structure). Detailed assay characteristics, including full descriptions of the assay components and cross reactivity's have been provided for the 11-oxoaetiocholanolone I, cortisol and corticosterone EIAs by Palme and Möstl (1997), 11-oxoaetiocholanolone II EIA by Möstl et al. (2002) and for the $5 \alpha$-pregnane-3 $\beta, 11 \beta, 21$-triol-20-one EIA by Touma et al. (2003). Subsequently, the sample sub-set related to the investigation of $\mathrm{fGCM}$ concentration stability post-defaecation was analysed using only the 11-oxoaetiocholanolone I and the $5 \alpha$-pregnane-3 $\beta, 11 \beta, 21$-triol-20-one EIAs. Finally, samples collected from free-ranging leopards at the MMGR and HWE study sites were analysed using only the $5 \alpha$-pregnane-3 $\beta, 11 \beta, 21$-triol-20-one EIA.

Serial dilutions of faecal extracts gave displacement curves that were parallel to the respective

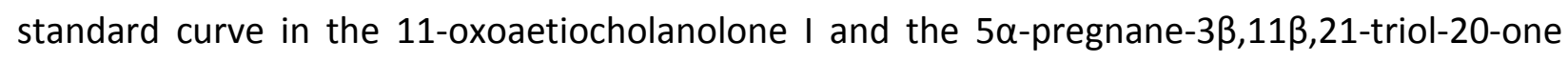
EIAs (relative variation (\%) of the slope of respective trend lines $<4 \%$ ). The sensitivities of the EIAs used were $0.6 \mathrm{ng} / \mathrm{g}$ dry weight (DW) (Cortisol, 11-oxoaetiocholanolone I and 11oxoaetiocholanolone II EIA), $1.8 \mathrm{ng} / \mathrm{g}$ DW (Corticosterone EIA) and $2.4 \mathrm{ng} / \mathrm{g}$ (5 $\alpha$-pregnane-3 $\beta$ , 11 ,21-triol-20-one EIA) respectively. Intra-assay coefficients of variation of low- and highvalue quality controls were $4.8 \%$ and $5.8 \%$ (Cortisol EIA), $4.0 \%$ and $4.8 \%$ (11oxoaetiocholanolone I EIA), 5.3\% and 5.8\% (11-oxoaetiocholanolone II EIA), 5.7\% and 5.9\% (Corticosterone EIA), and $4.6 \%$ and $5.7 \%$ (5 $\alpha$-pregnane-3 $\beta, 11 \beta, 21$-triol-20-one EIA) respectively. Inter-assay coefficients of variation of low- and high-value quality controls were only determined for 11-oxoaetiocholanolone I EIA (6.5\% and 11.6\%) and $5 \alpha$-pregnane-3 $\beta, 11$ $\beta$,21-triol-20-one EIA (6.2\% and $14.4 \%)$. All steroid concentrations are given as $\mu \mathrm{g} / \mathrm{g}$ faecal dry weight. All fGCM extractions and subsequent hormone analyses were performed at the Endocrine Research Laboratory, University of Pretoria, South Africa as described previously (Ganswindt et al. 2002). 


\section{Data analysis}

Due to the occurrence of biological stressors prior to ACTH administration, assay-dependent individual baseline $\mathrm{fGCM}$ concentrations were determined by using the median fGCM concentration of the four samples collected from $64.5 \mathrm{~h}$ post-ACTH administration onwards. Subsequently, assay-dependent fGCM concentration for each sample was expressed as a percentage (\%) using individual baseline fGCM concentrations as $100 \%$. To determine responses to physiological or biological stressors, the fGCM concentration (\%) of the first voided sample after the occurrence of each respective stressor was compared with respective individual baseline fGCM concentrations. Stability of fGCM concentration post-defaecation was calculated using the median $\mathrm{fGCM}$ concentration determined at time $=0 \mathrm{~h}(100 \%$ initial concentration), to calculate differences in fGCM concentration for each sample. Subsequently, mean differences in fGCM concentration for each triplicate sample set was calculated. The Chisquare test was used to determine statistically significant differences between the two storage treatments (full sun and full shade) tested. Descriptive statistics (overall median and range) and a Mann-Whitney Rank Sum test (MWRS) were used to compare fGCM concentrations determined from individuals at MMGR and HWE sites and for comparison of fGCM concentrations of males and females at and between study sites. At HWE, collected material was assigned (80-90\% confidence by CyberTracker level III accredited tracker) to either male or female individuals using track and sign interpretation (Liebenberg 2000) where possible ( $n=17$ out of $n=37$ ). Subsequently, HWE sex-assigned sample sets were compared using a MannWhitney U-test (MWU) after testing for normality with a Shapiro-Wilk test. Statistical analyses were performed using the software programme Statistica (v.13) and statistical significance was assumed when $P<0.05$. Data are presented as means $\pm S D$, medians and ranges where applicable. SigmaPlot (v.10) was used for all graphical presentation of data.

\section{RESULTS}

\section{ACTH challenge test and biological validation}

Using a set minimum increase of $100 \%$ as a target, the 11-oxoaetiocholanolone II EIA performed best for the male (334\% increase from $1.81 \mu \mathrm{g} / \mathrm{g}$ DW baseline concentration), but performed inadequately for the female $(33 \%$ increase from $3.88 \mu \mathrm{g} / \mathrm{g}$ DW baseline concentration). The 11-oxoaetiocholanolone I EIA performed adequately, showing an increase of $173 \%$ from baseline concentration $(0.48 \mu \mathrm{g} / \mathrm{g} \mathrm{DW})$ in the male and $130 \%$ increase from baseline concentration ( $0.37 \mu \mathrm{g} / \mathrm{g} \mathrm{DW})$ in the female. Overall, the $5 \alpha$-pregnane-3 $\beta, 11 \beta, 21$ - 
triol-20-one EIA performed best in both individuals; with a $331 \%$ increase from baseline concentration $(0.39 \mu \mathrm{g} / \mathrm{g} \mathrm{DW})$ reflected in the male, and a $203 \%$ increase from baseline concentration $(0.29 \mu \mathrm{g} / \mathrm{g} \mathrm{DW})$ reflected in the female (Table 1 and Figure 1). Peak fGCM concentrations were present in the first faecal sample post-ACTH administration ( $40.7 \mathrm{~h})$ across four of the five assays except for the Cortisol EIA, which measured a peak at 66 hours postinjection in the male (Table 1). Using the $5 \alpha$-pregnane-3 $\beta, 11 \beta, 21$-triol-20-one EIA, fGCM concentrations took longer to return to baseline in the male $87.0 \pm 33.9 \mathrm{~h}$ (mean $\pm \mathrm{SD}$; range $64.7-112.7 \mathrm{~h}$ ) than in the female $65.3 \pm 0.53 \mathrm{~h}$ (mean $\pm \mathrm{SD}$; range $65.0-65.8 \mathrm{~h}$ ). In the first sample voided post-separation, peak fGCM concentrations increased by $54.8 \%$ from baseline in the male $(47.4 \mathrm{~h})$ and by $30.5 \%$ from baseline in the female $(25.0 \mathrm{~h})$. Immobilization and translocation of a neighbouring Bengal tiger resulted in an increase of $170 \%$ (after $22.9 \mathrm{~h}$ ) and $141.3 \%$ (after $25.3 \mathrm{~h}$ ) from baseline fGCM concentrations in the male and female respectively (Figure 1).

\section{Stability of fGCM concentration post-defaecation}

Under full-sun conditions the 11-oxoaetiocholanolone I EIA showed a maximum decrease in fGCM concentration of $10 \%$ within the first hour and a maximum increase in $\mathrm{fGCM}$ concentration of $7 \%$ after $48 \mathrm{~h}$. Under full-shade conditions, the 11-oxoaetiocholanolone I EIA showed a maximum decrease in fGCM concentration of $20 \%$ after $48 \mathrm{~h}$ and a maximum increase of $8 \%$ after $72 \mathrm{~h}$ (Figure 2). In contrast, under full-sun conditions, the $5 \alpha$-pregnane-3 $\beta, 11 \beta, 21$-triol-20-one EIA showed a maximum decrease of $6 \%$ after $72 \mathrm{~h}$ and maximum increase of $6 \%$ after $144 \mathrm{~h}$. Under full-shade conditions, the $5 \alpha$-pregnane-3 $\beta, 11 \beta, 21$-triol20-one EIA measured a maximum decrease of $9 \%$ after $6 \mathrm{~h}$ and a maximum increase of $8 \%$ after $72 \mathrm{~h}$ (Figure 2). Distribution of fGCM concentration across sampling subsets did not differ between sun and shade conditions for the 11-oxoaetiocholanolone I EIA ( $\left.X^{2} p=0.61, d f=1\right)$ or the $5 \alpha$-pregnane-3 $\beta, 11 \beta, 21$-triol-20-one EIA $\left(\mathrm{X}^{2} \mathrm{p}=0.63, \mathrm{df}=1\right)$. Overall, the $5 \alpha$-pregnane$3 \beta, 11 \beta$,21-triol-20-one EIA performed best for measuring differences in $\mathrm{fGCM}$ concentrations and thus was used for further analysis of samples from free-ranging animals.

\section{Comparison of FGCM concentrations at different study sites}

In total seven samples were collected from the MMGR study site and 17 samples were collected from the HWE study site. Although overall median fGCM concentrations differed between the conservation area (MMGR: $0.79 \mu \mathrm{g} / \mathrm{g}$ DW) and the peri-urban area (HWE: $1.16 \mu$ g/g DW) study sites by $68 \%$, the groups were not significantly different (MWRS $T=86, n=16, p$ $=0.920)$. The range showed pronounced variation at both sites, with fGCM concentrations 


\begin{tabular}{|c|c|c|c|c|c|}
\hline Adult Male & Cortisol & $\begin{array}{l}\text { 11-oxo- } \\
\text { aetiocholanol- } \\
\text { one I }\end{array}$ & Corticosterone & $\begin{array}{l}\text { 11-oxo- } \\
\text { aetiocholanol- } \\
\text { one II }\end{array}$ & $\begin{array}{l}5 \alpha \text {-pregnane- } \\
3 \beta, 11 \beta, 21 \text {-triol- } \\
20 \text {-one }\end{array}$ \\
\hline Baseline fGCM concentration ( $\mu \mathrm{g} / \mathrm{g}$ DW) & 0.18 & 0.48 & 0.94 & 1.81 & 0.29 \\
\hline Peak fGCM concentration - Separation ( $\mu \mathrm{g} / \mathrm{g}$ DW) & 0.08 & 0.81 & 1.18 & 4.86 & 0.45 \\
\hline Hours after stressor to reach peak concentration & 47.35 & 47.35 & 47.35 & 47.35 & 47.35 \\
\hline Response (\%) & -55.16 & 67.54 & 24.94 & 168.12 & 54.75 \\
\hline Peak fGCM concentration - Translocation ( $\mu \mathrm{g} / \mathrm{g}$ DW) & 0.09 & 0.84 & 0.80 & 5.73 & 0.79 \\
\hline Hours after stressor to reach peak concentration & 22.80 & 22.80 & 22.80 & 64.55 & 22.80 \\
\hline Response (\%) & -51.36 & 75.44 & -14.51 & 216.33 & 170.96 \\
\hline Peak fGCM concentration - ACTH Challenge Test ( $\mu \mathrm{g} / \mathrm{g}$ DW) & 0.20 & 1.11 & 1.79 & 7.85 & 1.25 \\
\hline Hours after injection to reach peak concentration & 65.7 & 40.66 & 40.66 & 40.66 & 40.65 \\
\hline Response (\%) & 13.04 & 129.91 & 90.30 & 333.55 & 331.19 \\
\hline Adult Female & Cortisol & $\begin{array}{l}\text { 11-oxo- } \\
\text { aetiocholanol- } \\
\text { one I }\end{array}$ & Corticosterone & $\begin{array}{l}\text { 11-oxo- } \\
\text { aetiocholanol- } \\
\text { one II }\end{array}$ & $\begin{array}{l}5 \alpha \text {-pregnane- } \\
3 \beta, 11 \beta, 21 \text {-triol- } \\
20 \text {-one }\end{array}$ \\
\hline Baseline fGCM concentration ( $\mu \mathrm{g} / \mathrm{g}$ DW) & 0.12 & 0.37 & 1.50 & 3.88 & 0.39 \\
\hline Peak fGCM concentration - Separation ( $\mu \mathrm{g} / \mathrm{g}$ DW) & 0.15 & 0.44 & 1.09 & 5.06 & 0.51 \\
\hline Hours after stressor to reach peak concentration & 24.35 & 24.35 & 24.35 & 24.35 & 24.35 \\
\hline Response (\%) & 23.15 & 21.20 & -27.82 & 30.31 & 30.46 \\
\hline Peak fGCM concentration - Translocation ( $\mu \mathrm{g} / \mathrm{g}$ DW) & 0.20 & 0.94 & 2.38 & 8.22 & 0.95 \\
\hline Hours after stressor to reach peak concentration & 25.33 & 25.33 & 21 & 21 & 25.33 \\
\hline Response (\%) & 62.69 & 155.34 & 26.95 & 111.93 & 141.34 \\
\hline Peak fGCM concentration - ACTH Challenge Test ( $\mu \mathrm{g} / \mathrm{g}$ DW) & 0.24 & 1.00 & 2.69 & 5.66 & 1.19 \\
\hline Hours after injection to reach peak concentration & 40.75 & 40.75 & 40.75 & 40.75 & 40.75 \\
\hline Response (\%) & 94.22 & 172.95 & 78.53 & 33.25 & 203.05 \\
\hline
\end{tabular}

\section{TABLE 1.}

Baseline and peak fGCM concentrations, \% increase and time taken to reach peak fGCM concentration for two adult leopards at Predator World, South Africa after perceiving three stressors (physical separation, immobilisation and translocation of a neighbouring Bengal tiger (Panthera tigris tigris) and ACTH administration for each of the five ElAs tested. 


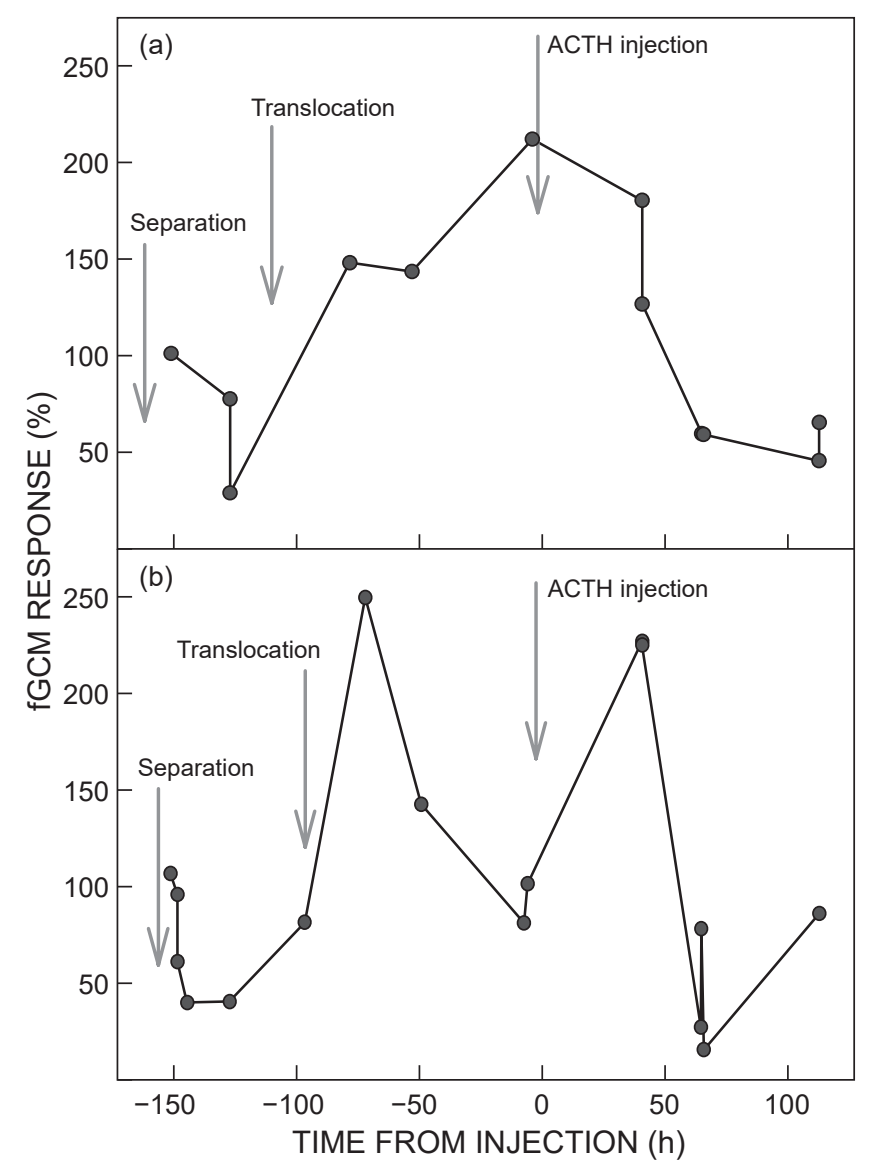

Figure 1: Longitudinal profiles of immunoreactive faecal gluco-corticoid metabolite (fGCM) concentration percentage increase determined using the most stable enzyme immunoassay

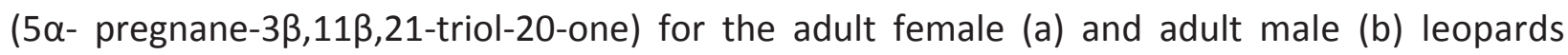
housed at Predator World following separa-tion, immobilisation-translocation of a neighbouring Bengal tiger (Panthera tigris tigris), and adrenocorticotrophic hormone (ACTH) administration. Vertical grey arrows indicate potential stress events 


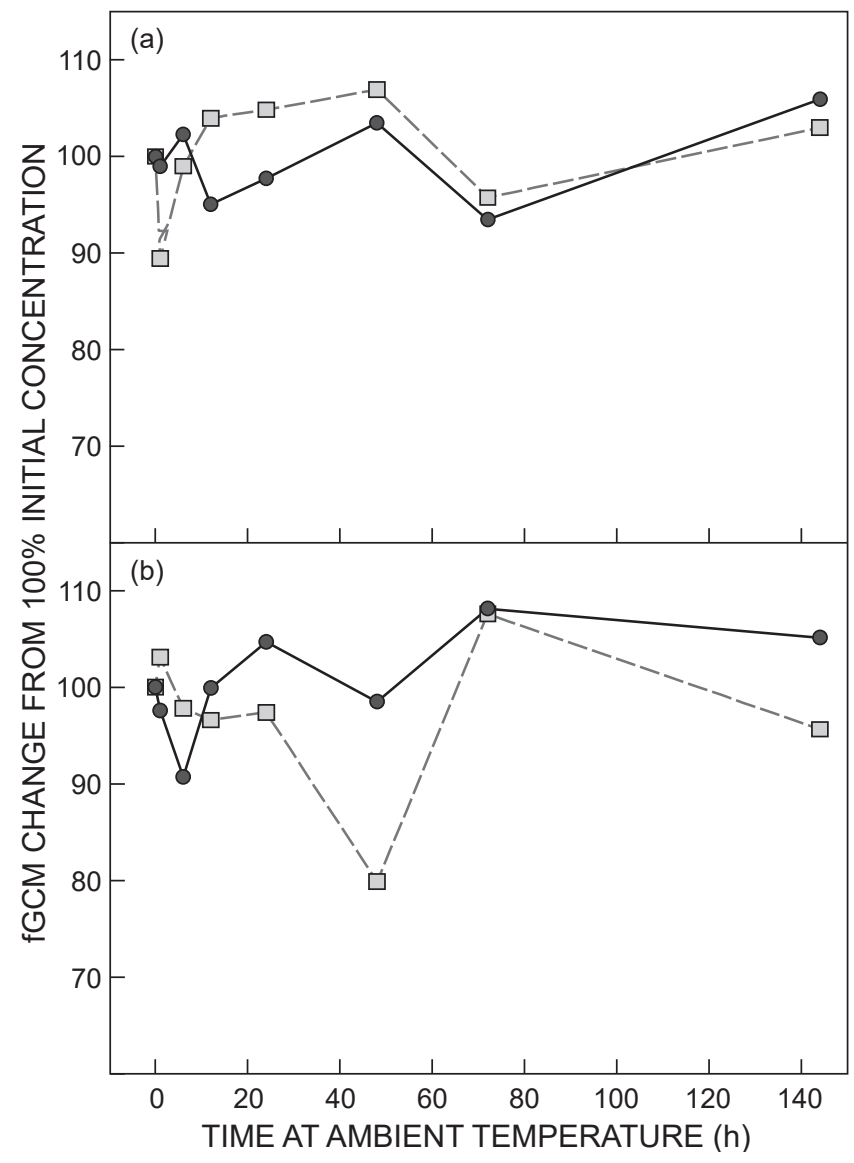

Figure 2: Changes in faecal glucocorticoid metabolite ( $\mathrm{fGCM}$ ) concentrations post-defaecation for the 11-oxoaetiocholanolone I enzyme immunoassay (grey broken line) and $5 \alpha$-pregnane$3 \beta, 11 \beta, 21$-triol-20-one concentrations (black solid line) over time for faeces stored in full sun (a) and full shade $(\mathrm{b})$ conditions 


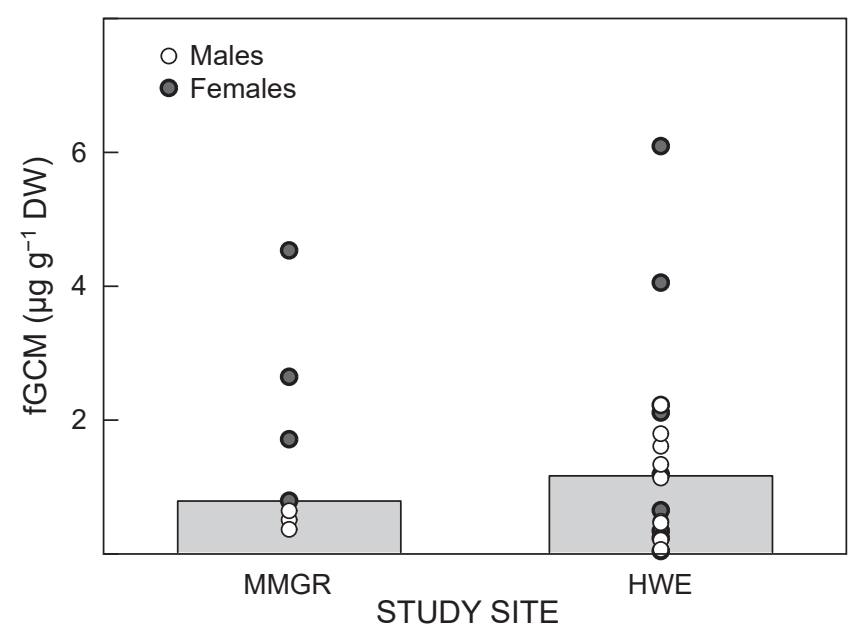

Figure 3: Box-bar plot for individual faecal glucocorticoid metabolite (fGCM) concentrations collected from males and females at the MalaMala Private Game Reserve (MMGR) and Hoedspruit Wildlife Estate (HWE) study sites. At the MMGR study site, samples were collected from known individuals and at HWE samples were assigned to different sexes using track and sign interpretation. Circles in each column represent fGCM concentrations of sampled individuals at each study site, and the bar in each column represents the median value of fGCM concentrations measured at each site 
measured in the MMGR animals $(0.36-4.53 \mu \mathrm{g} / \mathrm{g} \mathrm{DW})$ being similar to those measured in the HWE animals (0.02 - $6.09 \mu \mathrm{g} / \mathrm{g} \mathrm{DW})$. Overall median fGCM concentrations were $50 \%$ higher in MMGR females $(n=4)$ compared to males. Interestingly, two females were known to be pregnant or rearing young, and showed respective fGCM concentrations of $428 \%$ and $806 \%$ higher than the overall mean steroid concentrations measured in the males $(n=3)$ from the same site. At the HWE study site, samples assigned to males $(n=8)$ or females $(n=9)$ were not statistically different ( $\mathrm{MWU}=-0.82, \mathrm{n}=17, \mathrm{p}=0.41$ ). The range of $\mathrm{fGCM}$ concentrations allocated to females $(0.04-6.09 \mu \mathrm{g} / \mathrm{g} \mathrm{DW})$ was again greater than the range allocated to males $(0.06-1.79 \mu \mathrm{g} / \mathrm{g} \mathrm{DW})$ (Figure 3). However, if the two samples from females with the highest $\mathrm{fGCM}$ concentrations are excluded, the range of $\mathrm{fGCM}$ concentrations allocated to females $(0.04-2.22 \mu \mathrm{g} / \mathrm{g} \mathrm{DW})$ is similar to the fGCM concentrations measured in the males. Baseline concentration of the captive male $(0.29 \mu \mathrm{g} / \mathrm{g} \mathrm{DW})$ and captive female $(0.39 \mu \mathrm{g} / \mathrm{g}$ DW) at Predator World fall within the lower range of fGCM concentrations determined for freeranging males and females respectively.

\section{DISCUSSION}

Of the five enzyme immunoassays tested in this study, the cortisol and corticosterone ElAs performed poorly in both sexes, presumably because the majority of biologically active steroids are heavily metabolised before excretion and thus, specificity of the respective antibodies used are suboptimal (Möstl and Palme 2002). The three remaining group-specific EIAs that were tested revealed suitable results for at least one (11-oxoaetiocholanolone II) or both (11oxoaetiocholanolone $\mathrm{I}$ and $5 \alpha$-pregnane-3 $\beta, 11 \beta, 21$-triol-20-one) sexes for detecting physiologically and biologically meaningful changes in stress-related differences in fGCM concentrations in the leopard. Sex-related quantitative differences in fGCM concentrations in response to a stressor are not uncommon (Ludwig et al. 2013) as, irrespective of the principal glucocorticoid present in the blood, steroid hormones may be metabolised differently between sexes of the same species, resulting in sex-specific differences in metabolite composition within the faeces (Touma et al. 2003, Touma et al. 2004). Apart from the mechanisms involved, a number of species including African buffalo (Syncerus caffer Sparrman, 1779; Ganswindt et al. 2012), Nile crocodile (Crocodylus niloticus Laurenti, 1768; Ganswindt et al. 2014), spotted hyaena (van Meter et al. 2009) and bat-eared fox (Otocyon megalotis Desmarest, 1822; Le Roux et al. 2016) have been described to show sex-related differences in fGCM concentrations in response to an ACTH challenge. Further, respective sex-related differences in stress-induced 
glucocorticoid differences have been noted in closely related members of the cat family including the domestic cat (Felis catus Linnaeus, 1758; Young et al. 2004), clouded leopard (Neofelis nebulosa Griffith, 1821; Wielebnowski et al. 2002; Young et al. 2004), jaguar (Panthera onca Linnaeus, 1758; Conforti et al. 2011), cheetah (Acinonyx jubatus Schreber, 1775; Ludwig et al. 2013), lion (Creel et al. 2013) and tiger (Bhattacharjee et al. 2015). Of course, the differences in stress-related fGCM alterations found between the two animals, could also reflect the variation in individual coping ability within specific captive situations (Wielebnowski et al. 2002; Ludwig et al. 2013; Chosy et al. 2014).

Immunoreactive fGCM concentrations can decrease or increase in relation to assay specificity depending on the fGCM stability post-defaecation (Lexen et al. 2008). A decrease in fGCM concentrations post-defaecation has been noted in sheep (Ovis aries Linnaeus, 1758; Lexen et al. 2008), brown hyaena (Parahyaena brunnea Thunberg, 1820; Hulsman et al. 2010) and Nile crocodile (Ganswindt et al. 2014), while marked increases have been noted in domestic cattle (Bos taurus Linnaeus, 1758), horses (Equus ferus Linnaeus, 1758), pigs (Sus scrofus domesticus Linnaeus, 1758) (Möstl et al. 1999) and sheep (Lexen et al. 2008). In contrast, Meza-Cruz et al. (2014) demonstrated that for the jaguar, changes in immunoreactive fGCM concentrations post-defaecation were not significant, with $\mathrm{fGCM}$ concentrations remaining relatively stable for up to five days in both the wet and dry season. In the current study, immunoreactive fGCM concentrations measured with the $5 \alpha$-pregnane-3 $\beta, 11 \beta, 21$-triol-20-one EIA showed overall less variation and greater stability for up to 6 days post-defaecation compared to respective steroid concentrations determined with the 11-oxoaetiocholanolone I EIA. A reliable measurement of fGCM concentrations in leopard faeces that is up to six days old allows a more feasible approach for monitoring free-roaming individuals, for example, designated transects could be checked and cleared every five to six days without having to precisely age faecal samples. However, potential seasonal variability in the stability of fGCM concentrations in the leopard should be further assessed in future studies.

Overall median fGCM concentrations were $68.1 \%$ higher in the peri-urban HWE study site than they were in the conservation area of MMGR. The data should however be interpreted with caution, as samples from the MMGR study site were collected from only seven (four females and three males) of apparently 27 individual animals using the property and might therefore not be a true representation of fGCM concentrations of animals within that population. Further, samples collected from the seven animals utilising the HWE study site could not be assigned to specific individuals. Despite these limitations, our initial findings suggest that 
factors at the HWE study site, contributed to overall higher individual fGCM concentrations as well as greater variability than those determined in the conservation area of the MMGR study site. This is in line with studies conducted on elk (Cervis elephas Linnaeus 1758), wolves (Canis lupus Linnaeus, 1758; Creel et al. 2002), spotted hyaena (Van Meter et al. 2009), lion (Creel et al. 2013), and tiger (Bhattacharjee et al. 2015), which demonstrate that anthropogenic disturbance can result in elevated fGCM concentrations. Although small data sets were obtained from the MMGR and HWE study sites during this study, higher variability driven by some extreme values was found in measured fGCM concentrations of females at both sites. This pattern matches findings in female South African Lesser Galagos (Galago moholi Smith, 1836; Scheun 2015) and female white rhinoceros (Ceratotherium simum simum Burchell, 1817; Badenhorst et al. 2016) that demonstrate a potential link between alterations in pregnancyrelated progestagen and $\mathrm{fGCM}$ concentrations.

Information from known female individuals at the MMGR study site provided some insights and possible explanation for these sex-related differences. Two of the four monitored females at the MMGR study site showed particularly high fGCM values. Anecdotal and observation data related to sightings, associations and denning behaviour gathered by the MalaMala safari guides during daily drives, showed that the two MMGR females demonstrating comparatively high fGCM values were pregnant and approaching parturition or rearing young. Interestingly, the highest $\mathrm{fGCM}$ concentrations determined from the HWE sample set were also assigned to females. Further studies specifically designed to assess the link between adrenocortical activity and the phases of reproduction in both captive and free-ranging leopards would however be necessary to better interpret the patterns detected in the current study. Factors such as age, temperature, food availability, life history stages, levels of habituation and others (McNab 2002; Conforti et al. 2011; Naidenko et al. 2011, Goymann 2012) could also contribute to the variability in $\mathrm{fGCM}$ concentrations measured in these individuals. Further studies investigating the effects of these variables on $\mathrm{fGCM}$ concentrations are therefore necessary.

The ability to reliably assess adrenocortical function in male and female leopards using the $5 \alpha$ pregnane-3 $\beta, 11 \beta, 21$-triol-20-one EIA which performed best overall, provides a useful noninvasive tool to further examine both intrinsic (cyclicity, pregnancy, lactation) and extrinsic (persecution in farming communities, levels of tourist activity, human-predator conflict situations) factors potentially acting as environmental stressors, and thus facilitate the development of locally applicable leopard management and conservation strategies for freeranging and captive individuals. 


\section{REFERENCES}

Badenhorst M, Otto M, van der Goot AC, Ganswindt A. 2016. Stress steroid levels and the shortterm impact of routine dehorning in female Southern white rhinoceroses (Ceratotherium simum simum). African Zoology 51: $211-215$.

Bhattacharjee S, Kumar V, Chandrasekhar M, Malviya M, Ganswindt A, Ramesh K, Sankar K, Umapathy G. 2015. Glucocorticoid stress responses of reintroduced tigers in relation to anthropogenic disturbance in Sariska Tiger Reserve in India. PLOS ONE 10: e0127626.

Boitani L. 1999. A databank for the conservation and management of the African mammals. Roma, Italy: Instituto di Ecolgia Applicata.

Chosy J, Wilson M, Santymire R. 2014. Behavioural and physiological response in felids to exhibit construction. Zoo Biology 33: 267 - 274.

Conforti VA, Morato RG, Augusto AM, de Oliveira e Sousa L, de Avila DM, Brown JL, Reeves JJ. 2011. Non-invasive monitoring of adrenocortical function in captive jaguars (Panthera onca). Zoo Biology 30: 1 - 16.

Creel S, Christianson D, Scheutte P. 2013. Glucocorticoid stress response in lions in relationship to group composition, human land use, and proximity to people. Conservation Physiology 1: $\cot 021$.

Creel S, Fox JE, Hardy A, Sands J, Garrott B, Peterson RO. 2002. Snowmobile activity and glucocorticoid stress responses in wolves and elk. Conservation Biology 16: 809 - 814.

Fisher JT, Erasmus BFN, Witkowski ETF van Aardt J, Asner GP, Wessels KJ, Mathieu R. 2014. Management approaches of conservation areas: differences in woody vegetation structure in a private and a national reserve. South African Journal of Botany 90: 146 - 152.

Ganswindt SB, Myburgh JG, Cameron EZ, Ganswindt A. 2014. Non-invasive assessment of adrenocortical function in captive Nile crocodiles (Crocodylus niloticus). Comparative Biochemistry and Physiology Part A: Molecular and Integrative Physiology 177: 11 - 17. 
Ganswindt A, Tordiffe ASW, Stam E, Howitt MJ, Jori F. 2012. Determining adrenocortical activity as a measure of stress in African buffalo (Syncerus caffer) based on faecal analysis. African Zoology 47: 261 - 269.

Ganswindt A, Heisterman M, Borragan S, Hodges JK. 2002. Assessment of testicular endocrine function in captive African elephants by measurement of urinary and faecal androgens. Zoo Biology 21: 27 - 36.

Goymann W. 2012. On the use of non-invasive hormone research in uncontrolled, natural environments: the problem with sex, diet, metabolic rate and the individual. Methods in Ecology and Evolution 3: 757 - 765.

Hayward MW, Henschel P, O’Brien J, Hofmeyr M, Balme G, Kerley GIH. 2006. Prey preferences of the leopard (Panthera pardus). Journal of Zoology 270: 298 - 313.

Hulsman A, Dalerum F, Ganswindt A, Münscher S, Bertschinger HJ, Paris M. 2010. Non-invasive monitoring of glucocorticoid metabolites in brown hyaena (Hyaena brunnea) feces. Zoo Biology 30: 451 - 458.

Jacobson AP, Gerngross P, Lemeris JR Jr., Schoonover RF, Anco C, Breitenmoser- Würsten C, Durant SM, Farhadinia MS, Henschel P, Kamler JF, Laguardia A, Rostro-Garcí a S, Stein AB, Jacobson LD. 2016 Leopard (Panthera pardus) status, distribution, and the research efforts across its range. Peer J 4:e1974.

Kersey DC, Dehnhard M. 2014. The use of non-invasive and minimally invasive methods in endocrinology for threatened mammalian species conservation. General and Comparative Endocrinology 203: 296 - 306.

Le Roux A, Botha H, Dalerum F, Ganswindt A. 2016. Non-invasive measurement of adrenocortical activity in a myrmecophageous mammal, the bat-eared fox. African Zoology 1: $47-51$. 
Lexen E, El-Bahr SM, Sommerfeld-stur I, Palme R, Möstl E. 2008. Monitoring the adrenocortical response to disturbances in sheep by measuring glucocorticoid metabolites in the faeces. Veterinary Medicine Austria 95: 64 - 71.

Liebenberg L. 2000. Tracks and tracking in Southern Africa. Cape Town: Struik Publishers

Ludwig C, Wachter B, Silinski-Mehr S, Ganswindt A, Bertshinger H, Hofer H, Dehnhard M. 2013. Characterisation and validation of an enzyme immunoassay for the non-invasive assessment of faecal glucocorticoid metabolites in cheetahs (Acinonyx jubatus). General and Comparative Endocrinology 180: 15 - 23.

Macdonald DW, Loveridge AJ. 2010. Biology and Conservation of Wild Felids. Oxford, England: Oxford University Press.

Marker LL, Dickman AJ. 2005. Factors affecting leopard (Panthera pardus) spatial ecology, with particular reference to Namibian farmlands. South African Journal of Wildlife Research 35: $105-115$.

Martin RB, De Meulenaar T. 1988. Survey of the status of the leopard (Panthera pardus) in subSaharan Africa. Lausanne, Switzerland: Secretariat of the Convention on International Trade Endangered Speices of Wild Fauna and Flora.

McNab BK. 2002. The physiological ecology of vertebrates: a view from energetics. Ithaca, New York: Cornell University Press.

Mesa-Cruz JB, Brown JL, Kelly MJ. 2014. Effects of natural environmental conditions on faecal glucocorticoid metabolite concentrations in jaguars (Panthera onca) in Belize. Conservation Physiology 1: cou039.

Möstl E. 2014. Glucocorticoids, their metabolites and their measurement in various animal species. Medycyna Wterynaryjna 70: 524 - 529. 
Möstl E, Maggs JL, Schrötter G, Besenfelder U, Palme R. 2002. Measurement of cortisol metabolites in faeces of ruminants. Veterinary Research Communications. 26: 127 - 139.

Möstl E, Palme ER. 2002 Hormones as indicators of stress. Domestic Animal Endocrinology 23: $67-74$.

Möstl E, Messmann S, Bagu E, Robia C, Palme R. 1999. Measurement of glucocorticoid metabolite concentrations in faeces of domestic livestock. Journal of Veterinary Medicine Series A 46: 621 - 631.

Naidenko SV, Ivanov EA, Lukarevskii VS, Hernandez-Blanco JA, Sorokin MN, Litvinov MN, Kotlyar AK, Rozhnov VV. 2011. Activity of the hypothalamo-pituitary-adrenals axis in the Siberian tiger (Panthera tigris altaica) in captivity and in the wild, and its dynamics throughout the year. Biology Bulletin 38: 301 - 305.

Palme R, Rettenbacher S, Touma C, El-Bahr SM, Möstl E. 2005. Stress hormones in mammals and birds: comparative aspects regarding metabolism, excretion, and non-invasive measurement in faecal samples. Annals of the New York Academy of Sciences 1040: 162 171.

Palme R, Möstl E. 1997. Measurement of cortisol metabolites in faeces of sheep as a parameter of cortisol concentration in blood. International Journal of Mammal Biology 62: 192 - 197.

Rimbach R, Link A, Heistermann M, Gómez-Posada C, Galvis N, Hymann EW. 2013. Effects of logging, hunting and forest fragment size on physiological stress levels of two sympatric ateline primates in Columbia. Conservation Physiology 1. Cot031.

Sapolsky RM. 2002. Endocrinology of the stress- response. In: Becker JB, Breedlove SM, Crews D, McCarthy MM. (eds). Behavioural Endocrinology. Cambridge MA, US: MIT Press

Scheun J. 2015. Reproductive activity and its endocrine correlates in the African lesser bushbaby, Galago moholi. PhD thesis, University of Pretoria, South Africa. 
Schwarzenberger F. 2007. The many uses of non-invasive faecal steroid monitoring in zoo and wildlife species. International zoo yearbook 41:52 - 74.

Selye H. 1936. A syndrome produced by diverse nocuous agents. Nature 138: 32 - 34.

Sheriff MJ, Dantzer B, Delehanty B, Palme R, Boonstra R. 2011. Measuring stress in wildlife: techniques for quantifying glucocorticoids. Oecologia 4: 869 - 887.

Stein AB, Hayssen V. 2013. Panthera pardus (Carnivora: Felidae. Mammalian Species 45: 30 48.

Swanepoel LH, Blame G, Williams S, Power RJ, Snyman A, Gaigher I, Senekal C, Martins Q, Child MF. 2016. A conservation assessment of Panthera pardus. In: Child MF, Roxburgh L, Do Linh San E, Raimondo D, Davies-Mostert HT (eds). The 2016 red list of mammals of South Africa, Swaziland and Lesotho. South African National Biodiversity Institute and Endangered Wildlife Trust, South Africa.

Swanepoel LH, Somers MJ, van Hoven W, Shiess-Meier M, Owen C, Snyman A, Martins Q, Senekal C, Camacho G, Boshoff W, Dalerum F. 2014. Survival rates and causes of mortality in leopards Panthera pardus in Southern Africa. Oryx 4: 595 - 603.

Swanepoel LH, Lindsey P, Somers MJ, van Hoven W, and Dalerum F. 2012. Extent and fragmentation of suitable leopard habitat in South Africa. Animal Conservation 16: 41 - 50.

Touma C, Palme R. 2005. Measuring faecal glucocorticoid metabolites in mammals and birds: the importance of validation. Annals of the New York Academy of Sciences 1046: 54 - 74.

Touma C, Palme R, Sachser N. 2004. Analyzing corticosterone metabolites in fecal samples of mice: a non-invasive technique to monitor stress hormones. Hormones and Behaviour 45: $10-22$. 
Touma C, Sachser N, Möstl E, Palme R. 2003. Effects of sex and time of day on metabolism and excretion of corticosterone in urine and faeces of mice. General and Comparative Endocrinology 3: 267 - 278.

Van Meter PE, French JA, Dloniak SM, Watts HE, Kolowski JM, Holekamp KE. 2009. Faecal glucocorticoids reflect socio-ecological and anthropogenic stressors in the lives of wild spotted hyaenas. Hormones and Behaviour 55: 329 - 337.

Viljoen F, Moller JJ. 2015. Environmental Management Plan, Hoedspruit Wildlife Estate, Limpopo Province. Technical Report by Bateleur Ecological Services.

Wielebnowski NC, Fletchall N, Carlstead K, Busso JM, Brown JL. 2002. Non-invasive assessment of adrenal activity associated with husbandry and behavioural factors in the North American clouded leopard population. Zoo Biology 21: 77 - 98.

Williams ST, Williams KS, Lewis BP, Hill RA. 2017. Population dynamics and threats to an apex predator outside protected areas: implications for carnivore management. Royal Society Open Science 4: 161090.

Young KM, Walker SL, Lanthier C, Waddell WT, Monfort SL, Brown JL. 2004. Non-invasive monitoring of adrenocortical activity in carnivores by faecal glucocorticoid analysis. General and Comparative Endocrinology. DOI.10.1016/j.ygcen.2004.02.016. 